$10-8-2021$

\title{
Book Review: Last Train to Auschwitz The French National Railways and the Journey to Accountability
}

Timothy Plum

George Mason University

Follow this and additional works at: https://digitalcommons.usf.edu/gsp

\section{Recommended Citation}

Plum, Timothy (2021) "Book Review: Last Train to Auschwitz The French National Railways and the Journey to Accountability," Genocide Studies and Prevention: An International Journal: Vol. 15: Iss. 2: $55-57$.

Available at: https://digitalcommons.usf.edu/gsp/vol15/iss2/9

This Book Review is brought to you for free and open access by the Open Access Journals at Digital Commons @ University of South Florida. It has been accepted for inclusion in Genocide Studies and Prevention: An International Journal by an authorized editor of Digital Commons @ University of South Florida. For more information, please contact digitalcommons@usf.edu. 


\title{
Book Review: Last Train to Auschwitz: The French National Railways and the Journey to Accountability
}

\author{
Timothy Plum \\ George Mason University \\ Fairfax, Virginia, U.S.A.
}

\author{
Last Train to Auschwitz: The French National Railways and the Journey to Accountability \\ Sarah Federman \\ Madison, University of Wisconsin Press, 2021 \\ 344 Pages; Price: \$79.95 Hardcover
}

Reviewed by Timothy Plum

George Mason University

In the Last Train to Auschwitz: The French Railways and the Journey to Accountability Sarah Federman has placed a new understanding of transitional and social justice discourse in World War II and modern literature. The rise of social justice movements around unchecked police powers, corporate greed, and government malfeasance, along with corporate accountability to past deeds factor heavily in this narrative. Federman's book reminds us that the present-day issues we struggle with have historic and surprising roots. For example, paradoxes of identityis a corporation a person? Is it a sentient being? Do corporations owe a debt to society for wrongs and ills of the past? The latter question raises disagreement among the most harmedHolocaust survivors. Federman's book places renewed focus on corporate accountability through victims' and survivors' eyes. Delving into the human condition through one of the most heinous acts in human history, Federman examines corporate responsibility over decades from the acts of barbarity to the modern-day.

Gleaned from her Ph.D. dissertation, Last Train to Auschwitz tells of the Société nationale des chemins de fer français (SNCF) railroad and its complicity with Nazi Germany during the occupation of France from 1940 to 1944. Argued mainly from a French Holocaust survivor's perspective, the book looks at the accountability of the SNCF transport of approximately 70,000 people to Auschwitz and other camps. Taking the reader through multiple countries, legal arguments, survivor testimony, SNCF records, federal and state legislation, and officials of the SNCF railway in their own words to decide if a corporation can be held liable, and should it be seventy plus years on from the events.

Reaching into distant memories touched off from an unlikely source brought Federman to an unlikely subject. A request from a history professor to "find out if those French train drivers kept their jobs after the war" 1 and an etching of a name, Sarah Federman in the Treblinka death camp in $2009,{ }^{2}$ became the inspiration for this book. The source for inspiration can come from many places, and indeed few can be as wrenching as seeing your name on a wall of the murdered. Federman could have made this into a personal story around her Jewish ancestry a central device; instead, the emotional journey acts as a bridge to history. It reminds us the connections are genuine and visceral, even as the author remained neutral for the sake of academic rigor.

The narrative goes beyond corporate accountability giving voice to the victims and survivors, sitting down to tea, leafing through scrapbooks, the reader understands the people on a human level. The SNCF is given a bit of humanity from interviews and understanding how the corporation has paid for memorials, victim's funds, plaques, but never directly to the

\footnotetext{
1 Sarah Federman, Last Train to Auschwitz: The French Railways and the Journey to Accountability (Madison: University of Wisconsin Press, 2021), xii.

2 Ibid., xiii.
}

Timothy Plum. "Book Review: Last Train to Auschwitz: The French National Railways and the Journey to Accountability." Genocide Studies and Prevention 15, no. 2, 55-57. https://doi.org/10.5038/1911-9933.15.2.1839.

(C) 2021 Genocide Studies and Prevention. 
victims. ${ }^{3}$ Using a different font in the text of the book as "voices from the last train" placed at the end of each chapter gives a definitive space for victims and survivors and augments the argument of each chapter; it was welcome to read and understand directly from the most affected.

The SNCF is today the French railroad system; by combining seven railroad lines in 1938 the French government nationalized the rail system. When France fell on June 22, 1940, the nationalized rail system was easier to gain control under Article XIII of the occupation agreement than the independent lines would have been for total control of rail. As Federman shows, rail in France was critical everyday survival. At the height of World War II and Nazi occupation, the railroad employed approximately 500,000 people (about 250,000 today). The SNCF did remain with a sense of autonomy from the Nazi regime through management and control of the rolling stock. ${ }^{4}$

Federman's use of the trains of Convoy 77 and 78, last to leave Paris and Lyon respectively for Auschwitz are used as narrative devices to follow throughout the text that allows the reader to follow Daniel and Samuel, brothers on Convoy 77 and Estéra on Convoy 78. ${ }^{5}$ Through their eyes, we get the sense of traveling away from home, in many instances, never to return. What did the few survivors such as Daniel, Samuel, or Estéra and others return to? They found destroyed homes, missing family members, and little to no help and obstruction from banks and others unwilling to restore their monies or recognize their previous lives. ${ }^{6}$ Federman's use of the narrative loop of the train departure and arrival to Auschwitz or the return home after the war helps to bring an understanding to the survivors of the abuse upon leaving home, travel to Auschwitz, and the return home riding the same trains that delivered death and carnage. The reaction is visceral to the reader, giving the reader the real sense of the train journey and centrality to life, death, and survival.

Transitional justice ${ }^{7}$ is not a panacea and Federman uses stories of victims and survivors that seventy plus years on are still seeking through transitional justice mechanisms of transparency, apologies, compensation, commemoration, and trauma service, ${ }^{8}$ recognition from the world as the Holocaust slips from our consciousness and understanding. Inclusion in schools curriculum is shrinking as deniers gain strength in numbers and it is used as a punchline to compare behaviors between groups.

Building the case of SNCF complicity from the occupation to deportations into modern times allows the reader to glimpse the historic atrocities today. The conditions and types of trains used, merchandise cars (les wagons de merchandise), or cattle cars as commonly referred to in U.S. English. With little water, one bucket per car, and a bare bit of bread for fifty people per car, twenty cars to a train, and 1,000 people transported to almost certain death. ${ }^{9}$ Federman notes the reports, movies, and books over the decades following the war that brought unwanted attention to corporations, including the SNCF.10

The SNCF claimed after the war and to the present day that it operated without control and received no remuneration for the transport to the camps. As the author points out from survivors and documents, this was not true. ${ }^{11}$ The SNCF was regarded as heroes to the French people in the immediate aftermath of the war; trials were held for persons, not corporations.

\footnotetext{
3 Ibid., 133-140.

4 Ibid., 32-36.

5 Ibid., 42.

6 Ibid., 108-109, 114, 213.

7 Transitional Justice as defined by the International Center for Transitional Justice refers to the ways countries emerging from periods of conflict and repression address large-scale or systematic human rights violations so numerous and so serious that the normal justice system will not be able to provide an adequate response.

8 Federman, Last Train to Auschwitz, 6.

${ }^{9}$ Ibid., 51.

10 Ibid., 111-113.

11 Ibid., 59.
} 
Monetary remuneration would wait for many decades. By the 1980s, the façade of heroism was slipping from the SNCF but strangely not from other companies such as Hugo Boss, Volkswagen, the Reimann Family, and JAB Holdings, with many household brands including Dr. Pepper, Krispy Kreme Donuts, Panera Bread, Peets Coffee, Keurig, Au Bon Pain, Pret a Manger, Einstein's Bagels, Jimmy Choo, and Coty. ${ }^{12}$ Federman acknowledges in the introduction that a portion of the book is from the U.S. perspective, various states legislative actions, and survivor testimonies, giving the reader an international sense. Without coverage of these areas, the survivors and descendants of victims would not have received as much acknowledgment and voice in the fight to hold those responsible accountable.

In the concluding chapter of the book the reader reviews the road traveled on the rails, in the courtrooms, gardens, and sitting rooms through seventy years as victim, hero, and perpetrator to understand the SNCF better, but more importantly, to understand themselves in the past seventy plus years. ${ }^{13}$ Seventy years passed by quickly in the narrative. By examining the past, Federman placed the interviewees at the intersection of the Holocaust and today. A deep and revealing work built from personal experiences and unwavering scholarly research, Last Train to Auschwitz makes a significant contribution to existing scholarship on corporate accountability and broadly transitional justice.

12 Ibid., 3.

13 Ibid., 209. 